\title{
Multisectoral development for improved health outcomes: evaluation of community-based initiatives in the Islamic Republic of Iran
}

\author{
M.R. Sheikh, ${ }^{1}$ M.M. Afzal, ${ }^{1}$ S.Z. Ali, ${ }^{2}$ A. Hussain ${ }^{2}$ and R. Shehzadi ${ }^{2}$
}

$$
\begin{aligned}
& \text { التنمية المتعددة القطاعات لتحقيت حصائل صحية محسَّنّة: تقييم للمبادرات المجتمعية في جمهورية إيران الإسلامية }
\end{aligned}
$$

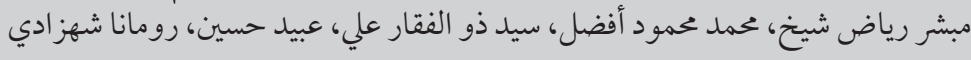

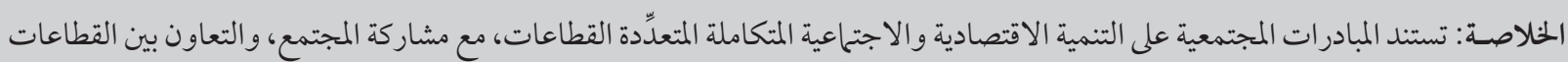

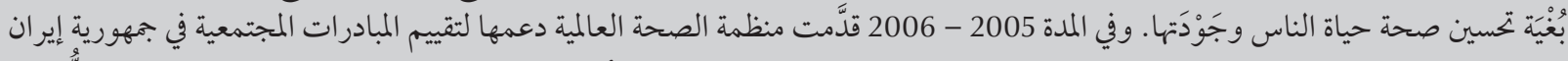

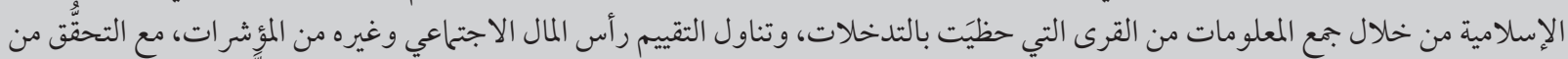

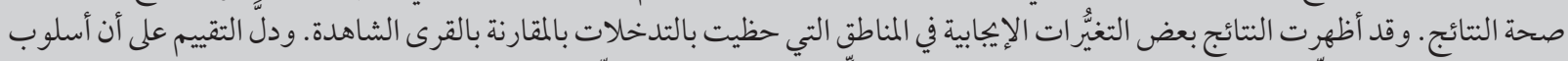

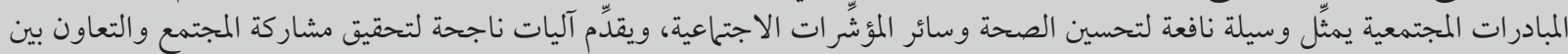

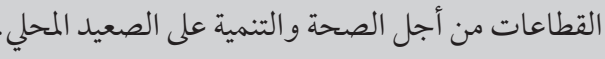

ABSTRACT Community-based initiatives $(\mathrm{CBI})$ are based on integrated multisectoral socioeconomic development with community participation and intersectoral support to improve the health and quality of life of the people. During 2005-06 the World Health Organization supported an evaluation of CBI in the Islamic Republic of Iran by collecting information from intervention villages on social capital and other indicators, with validation of the findings. The data showed some positive changes in the intervention areas compared with control villages. The evaluation suggests that the $\mathrm{CBI}$ approach is a useful tool for improving health and social indicators and providing mechanisms for community-based participation and intersectoral collaboration for health and development at the local level.

Développement multisectoriel pour des résultats sanitaires améliorés : évaluation d'initiatives communautaires dans la République islamique d'Iran

RÉSUMÉ Pour obtenir une amélioration de la santé et de la qualité de vie des populations, les initiatives communautaires s'appuient sur le développement socio-économique multisectoriel et intégré, la participation de la communauté et le soutien intersectoriel. En 2005 et 2006, I'Organisation mondiale de la Santé a soutenu une évaluation des initiatives communautaires en République islamique d'Iran, en collectant des informations sur le capital social ainsi que d'autres indicateurs, dans les villages bénéficiant d'interventions. Les données recueillies ont ensuite été validées. Elles ont révélé des changements positifs dans les zones d'intervention, par rapport aux villages témoins. Il ressort de cette évaluation que les initiatives communautaires constituent une approche utile pour améliorer les indicateurs sanitaires et sociaux ainsi que pour mettre en place des mécanismes permettant la participation communautaire et et la collaboration intersectorielle pour la santé et le développement au niveau local. 


\section{Introduction}

The globally accepted definition of health - "a state of complete physical, mental and social well-being and not merely the absence of disease or infirmity" [1] — highlights the need to address all the determinants of health in a comprehensive manner. Acknowledging this fact, the World Health Organization's Regional Office for the Eastern Mediterranean (EMRO) has since the 1980s been advocating and actively supporting community-based initiatives (CBI) for health and human development in its Member States [2].

Improved quality of life has been recognized as the essential prerequisite to attain optimum levels of health. CBI aims to achieve this through integrated socioeconomic developments that address the determinants of health collectively through community empowerment rather than through a narrow focus on health care services [2]. It is based on the principles of selfreliance, self-financing and self-management by communities who are organized, empowered and actively participating, supported through coordinated intersectoral actions [3]. This approach facilitates access to essential social services, appropriate technologies, information and financial credit, with the explicit aim of promoting fair distribution of resources to achieve equity at the grassroots level [4]. CBI represent a conceptual shift away from implementing conventional but isolated development activities towards a more holistic development where the community itself assesses and prioritizes its needs, plans and implements feasible solutions and monitors and evaluates the outcomes, actively supported and assisted by the related government departments [5].

CBI encompass other initiatives such as basic development needs (BDN), the healthy city programme (HCP), the healthy village programme (HVP) and women in health and development (WHD). BDN and HVP are implemented primarily in rural areas with common objectives, structures and processes [6]. HCP operates in urban areas and aims to improve health and the environment by putting health on the local development agenda [7]. WHD are cross-cutting initiatives implemented through the existing structures of community-based programmes [8].

Currently in the Eastern Mediterranean Region, the BDN approach has been implemented in 14 countries, HCP in 16, HVP in 6 and WHD in 21; the programmes are at various stages of development [9]. The Islamic Republic of Iran initiated the HCP in Tehran during 1996 and established the National Coordination Council for Healthy Cities and Healthy Villages Programme (NCCHCHVP) in 1999. The BDN approach was introduced during 2000 [10]. Currently, HCP is actively implemented in 16 cities, covering a combined population of around 4.2 million; HVP covers 39 areas with a population of around 73 000; and BDN operates in 34 areas with a population 58000 , with some overlap with HVP areas.

EMRO has conducted evaluations of CBI in different countries, including Djibouti, Jordan, Pakistan, Sudan, Syrian Arab Republic and Yemen. With a view to further expansion of the programme in the Islamic Republic of Iran, especially its institutionalization in the health and development sectors, WHO commissioned an evaluation of CBI to assess the inputs, process, outputs and impact of the initiative.

\section{Methods}

\section{Study design}

The evaluation and its validation were carried out in 3 stages:

- An evaluation of the development of the CBI programme at national, district and grassroots levels through interviews with key stakeholders and a review of programme records.
- A cross-sectional survey of selected social and health indicators comparing CBI programme and control sites, with the emphasis on social capital. Social capital refers to the connections among individuals, social networks and norms of reciprocity and trustworthiness [11].

- Validation of the findings of the first 2 stages through interviews with randomly selected key informants, on-site field visits and a review of programme documents.

\section{Evaluation framework}

The evaluation was carried out using the CBI guidelines developed by EMRO [12] with some adaptation of the indicators and questions. The guidelines include advice about the composition of evaluation teams, data collection tools and procedures to follow. For the assessment of social capital, instruments were used from the toolkit developed by the social development department of the World Bank [13].

\section{Evaluation teams and study dates}

The multidisciplinary evaluation team was selected from relevant disciplines according to their roles and expertise and was led by an epidemiologist from Tehran University of Medical Sciences as the principal investigator. Team members were trained on the objectives, tools and methodology for 4 days during November 2005. Field visits and data collection were from November 2005 to February 2006. The validation of the findings was conducted during April 2006 by 2 international consultants from the Aga Khan Health Service, Pakistan to provide evidence-based confirmation of the evaluation results.

\section{Sampling of study sites and population}

According to the EMRO guidelines for evaluation of CBI [12], the evaluation was carried out only in areas with about 5 years' experience of programme intervention. Among the list of suitable 
programme areas, 5 were selected by stratified random sampling: Hammamlar, Mohammadsalehi, Shole, Hureh and Savadjan.

Thestudygroups for the first stagethe evaluation of the development of the CBI programme-included representatives of community groups such as city and village Islamic councils, village development committees, cluster representatives (community representatives, 1 selected by the community from its residents in each cluster of 25-30 houses) and local or national nongovernmental organizations (NGOs); members of the general public and beneficiaries of projects; policy-makers, government managers, health system officials, members of intersectoral teams (from health and related sectors and departments such as education, agriculture, livestock, social welfare, local government/municipality, women and youth etc.), CBI programme managers and staff at national and local level; and representatives of international organizations engaged in similar programmes.

In the second stage of the evaluation-the survey of selected social and health indicators - a comparative study was made between 5 selected intervention villages and 5 control villages, with 40 households chosen by systematic random sampling in each village (social capital indicators were evaluated only in $3 \mathrm{CBI}$ and 3 control villages). Members of 401 households were interviewed by the evaluation team ( 240 households in the 3 CBI and control villages where social capital indicators were studied). The sampling frames were obtained from the household records of health houses, which are present in almost all villages across the Islamic Republic of Iran.

\section{Data collection}

Data were collected by the evaluation teams by reviewing CBI programme documents at all levels, interviewing key informants and collecting data from available data sources such as: the health horoscope (a tool for compiling vital events of communities in the catchments area of each health house); surveillance data; and before and after surveys.

Qualitative data on the development of the programme was collected in CBI areas through 47 focus group discussions (FGDs) and 58 indepth interviews with key stakeholders. The recordings of interviews and FGDs were transcribed by public health students.

Available baseline data on selected social and health indicators for 2000 were compared with the relevant data for 2005 through a review of the programme documentation in CBI areas.

The social capital assessment tool (SOCAT) [13] was extensively used to collect social capital data from a total of 240 households in 6 villages ( 118 households in 3 CBI areas and 122 households in 3 control villages). Control villages were selected based upon the criteria of having similar demographic, geographic and social conditions as the case villages. The percentage of household members affiliated with at least 1 local association and the frequency with which they faced problems/ limitations accessing different public services were compared in CBI and control areas.

For the validation stage various tools, including questionnaires, checklists and interviews, were used to assess the evaluation methodology and tools. A validation matrix was developed based on the programme evaluation standards of the Joint Committee on Standards for Educational Evaluation [14].

\section{Analysis}

For the qualitative data analysis the written texts were carefully read and coded by the evaluation team. Statistical analysis of quantitative data was carried out using STATA, version 8.0 [15].

\section{Evaluation findings}

The key findings of the CBI evaluation are presented as: qualitative findings of the interviews and FGDs; baseline and follow-up data; and quantitative data on social capital.

\section{Qualitative findings of interviews and FGDs}

Table 1 summarizes the qualitative evaluation of selected programme elements based on the FGDs and indepth interviews with key stakeholders. Five important elements were addressed with key findings based upon selective indicators for each element, including links with national developmental plans, political commitment and intersectoral collaboration, community participation, capacity building and needs-based developmental projects.

\section{Baseline and follow-up data in $\mathrm{CBI}$ areas}

Table 2 summarizes the findings of the review of programme documentation in the sample of 5 CBI villages, comparing baseline data from 2000 with the data from 2005 after 5 years of experience of the intervention. The average household size ranged from 3.7 to 7.2 persons per household in 2000 and from 3.5 to 6.5 in 2005 . The total population in these 5 villages declined 4\%, from 8137 in 2000 to 7780 in 2005 . The under-1year-old population as a percentage of the total population of the CBI villages decreased from $1.9 \%$ in 2000 to $1.8 \%$ in 2005. After 5 years of implementation of CBI in the 5 villages, the percentage of households owning their own house increased from $86.0 \%$ to $94.3 \%$, having a sanitary latrine from $79.7 \%$ to $97.1 \%$ and having a bathroom increased from $73.3 \%$ to $92.4 \%$.

\section{Quantitative data on social capital in CBI and control villages}

As part of the evaluation of social capital the proportion of household members affiliated with at least 1 local association was assessed. Table 3 shows this indicator for $3 \mathrm{CBI}$ and 3 control villages. The mean rate of affiliation in the CBI villages was $26.3 \%$ [95\% confidence 


\begin{tabular}{|c|c|c|c|}
\hline Serial no. & Element & Indicators & Key findings \\
\hline 1 & $\begin{array}{l}\text { Links with national } \\
\text { developmental plans }\end{array}$ & $\begin{array}{l}\mathrm{CBI} \text { approach is linked with } \\
\text { relevant programmes and } \\
\text { partners }\end{array}$ & $\begin{array}{l}\text { Ministry of Welfare considering CBI approach in future } \\
\text { programmes } \\
\text { Fourth 5-year national plan has adopted CBI approach as } \\
\text { one strategy for social justice }\end{array}$ \\
\hline 2 & $\begin{array}{l}\text { Political commitment } \\
\text { and intersectoral } \\
\text { collaboration }\end{array}$ & $\begin{array}{l}\text { Sufficient degree of political } \\
\text { commitment is available. } \\
\text { Intrasectoral support } \\
\text { mechanisms are in place }\end{array}$ & $\begin{array}{l}\text { National council formed } 1996 \\
\text { National expert groups from } 15 \text { ministries and } \\
\text { organizations continuously provide support } \\
\text { Intersectoral committees and teams are functional }{ }^{\text {a }} \text { at } \\
\text { district levels }\end{array}$ \\
\hline 3 & $\begin{array}{l}\text { Community } \\
\text { participation }\end{array}$ & $\begin{array}{l}\text { Community is organized, } \\
\text { empowered, and } \\
\text { participates in local } \\
\text { development }\end{array}$ & $\begin{array}{l}\text { All CBI villages have functional }{ }^{\text {a }} \text { village development } \\
\text { committees } \\
\text { Communities voluntarily participate in different } \\
\text { developmental activities }\end{array}$ \\
\hline 4 & Capacity building & $\begin{array}{l}\text { Capacity building of } \\
\text { concerned stakeholders on } \\
\text { programme processes and } \\
\text { essential skills }\end{array}$ & $\begin{array}{l}\text { Since 2001, around } 50 \text { training workshops, with almost } \\
1500 \text { participants were organized in } 25 \text { districts across the } \\
\text { country } \\
\text { Specialized training has been conducted on health, } \\
\text { nutrition, environment, school health, life skills, social } \\
\text { issues and income generation }\end{array}$ \\
\hline 5 & $\begin{array}{l}\text { Needs-based } \\
\text { developmental } \\
\text { projects }\end{array}$ & $\begin{array}{l}\text { Evidence-based planning } \\
\text { and interventions carried out }\end{array}$ & $\begin{array}{l}\text { All CBI areas have had baseline surveys and determination } \\
\text { of their priority needs } \\
\text { All CBI areas have established a community development } \\
\text { fund } \\
\mathrm{CBI} \text { areas have established various kinds of 'pro-poor' } \\
\text { projects to address the development needs of the poor }\end{array}$ \\
\hline
\end{tabular}

${ }^{a}$ Functional means that committees or teams are performing CBI functions normally as planned in the programme.

interval (CI): $21.0 \%-31.7 \%]$ and in the control villages $22.7 \%$ (95\% CI: $17.3 \%-28.2 \%)$.

Respondents were asked if they or other household members had ever faced any limitations or problems in accessing essential public services. A smaller proportion of households in CBI villages compared with the control villages reported difficulty in accessing employment, loans, drinking water, solid waste management and agricultural consultation (Figure 1).

\section{Discussion}

According toWHO "The right approach for attaining the target of optimum level of health for all lies in the totality of human needs that can be achieved through integrated community development"
[5]. This theme paved the way for the development of theinnovative approach of CBI introduced by EMRO in its member states. The present evaluation of CBI in the Islamic Republic of Iran has shown some promising results. The continuity of activities of the national coordinating council, especially its expert group and the district intersectoral committees, for about a decade is proof of strong positive political commitment

\begin{tabular}{|c|c|c|c|c|c|c|c|c|c|c|}
\hline \multirow[t]{2}{*}{ Indicator } & \multicolumn{2}{|c|}{ Hammamlar } & \multicolumn{2}{|c|}{ Shole } & \multicolumn{2}{|c|}{$\begin{array}{l}\text { Mohammad } \\
\text { Salehi }\end{array}$} & \multicolumn{2}{|c|}{ Hureh } & \multicolumn{2}{|c|}{ Savadjan } \\
\hline & 2000 & 2005 & 2000 & 2005 & 2000 & 2005 & 2000 & 2005 & 2000 & 2005 \\
\hline No. of households & 131 & 145 & 217 & 218 & 271 & 259 & 800 & 791 & 387 & 391 \\
\hline Total population & 938 & 939 & 1236 & 1200 & 1433 & 1499 & 2971 & 2755 & 1559 & 1467 \\
\hline $\begin{array}{l}\text { No. of children under } \\
1 \text { year old }\end{array}$ & 33 & 22 & 7 & 10 & 28 & 27 & 59 & 59 & 26 & 21 \\
\hline $\begin{array}{l}\text { No. of households with } \\
\text { ownership of house }\end{array}$ & 126 & 145 & 198 & 205 & 235 & 247 & 607 & 717 & 388 & 388 \\
\hline $\begin{array}{l}\text { No. of houses with } \\
\text { sanitary latrine }\end{array}$ & 30 & 145 & 129 & 218 & 240 & 254 & 738 & 743 & 303 & 391 \\
\hline $\begin{array}{l}\text { No. of houses with } \\
\text { bathroom }\end{array}$ & 26 & 135 & 110 & 210 & 253 & 254 & 639 & 699 & 296 & 367 \\
\hline
\end{tabular}




\begin{tabular}{|c|c|c|c|c|c|}
\hline \multirow[t]{2}{*}{ Village type and name } & \multirow{2}{*}{$\begin{array}{c}\text { Mean } \\
\%\end{array}$} & \multirow[t]{2}{*}{ SD } & \multicolumn{3}{|c|}{ Percentile } \\
\hline & & & 25th & 50th & 75th \\
\hline \multicolumn{6}{|l|}{ CBI villages } \\
\hline Hurrah & 22 & 26 & 0 & 20 & 33 \\
\hline Savadjan & 26 & 29 & 0 & 20 & 33 \\
\hline Mohammadsalehi & 30 & 22 & 17 & 25 & 45 \\
\hline \multicolumn{6}{|l|}{ Control villages } \\
\hline Garmdarreh & 18 & 19 & 0 & 17 & 33 \\
\hline Shourab Saghir & 27 & 26 & 0 & 25 & 50 \\
\hline Chahar Rousta & 23 & 18 & 14 & 20 & 25 \\
\hline
\end{tabular}

$S D=$ standard deviation .

and ownership of the initiative. Establishment of community organizations and the active participation of the community in programme activities is the foundation of CBI. The rate of affiliation of household members with local associations was higher in CBI villages than control villages, suggesting that people in CBI areas in the Islamic Republic of Iran have become more proactive. This is one of the aims of CBI: for people to understand their priority needs and to strive for solutions through developmental activities. People in CBI areas also had better access to many public services. Our findings indicate positive changes in the intervention areas in many of the health, social and economic indicators. For example, although the data were not compared with control villages the rise in the proportion of households with sanitary latrines and bathrooms in CBI villages is indicative of an improved quality of life.

Despite some positive shifts in the health and development indicators, there are various critical challenges and constraints that need to be addressed when consolidating the programme in existing areas and scaling up and expanding it into new areas. A common problem with $\mathrm{CBI}$ is that coordination mechanisms need to be formalized to ensure effective inter- and intrasectoral collaborations for planning, implementation and monitoring. In addition to the institutionalization of the CBI approach within health and development sectors, another issue for CBI in general is that partnerships with stakeholders need to be strengthened to reduce the financial burden that is at present mainly in the health sector. The processes needs to be more decentralized with streamlining of supervision and monitoring mechanisms, reforming information system to cater for the changing needs of programme areas and efficient

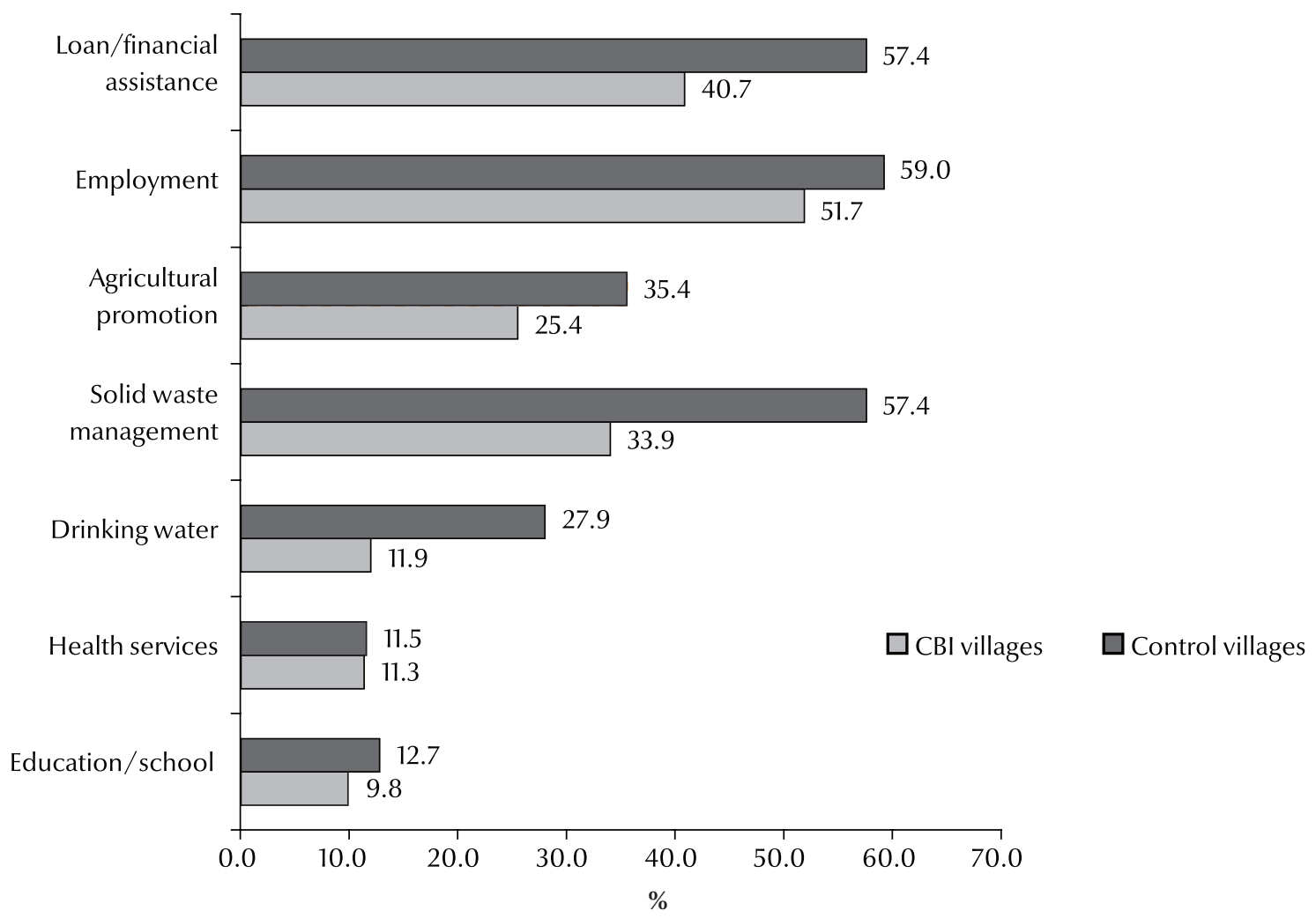

Figure 1 Percentage of household members in the community-based initiatives (CBI) programme villages and control villages who faced problems/limitations accessing different public services 
documentation of success experiences. The health and social components of the programme need to be further emphasized, implementing core and essential interventions; complemented with continuous capacity building and skills development programmes.

It is widely accepted that improved health is a fundamental input and outcome of socioeconomic development. Health for all cannot be achieved by the isolated interventions of the health sector alone; rather it requires an integrated multisectoral development approach. This use of participatory mechanisms for both communities and related sectors is the central theme of the CBI concept. Considering the positive findings of this evaluation of CBI in the Islamic Republic of Iran, it is strongly recommended that CBI should be strengthened, institutionalized and expanded to new areas in this and other countries of the EMR.

\section{Acknowledgements}

Special appreciation to the following for their contribution during the evaluation of community-based initiatives and its validation in the Islamic Republic of Iran: Dr. Abbas Motivalian, Assistant
Professor of Epidemiology, Iran University of Medical Sciences; Dr Majid Tavakoli, National CBI Office, Ministry of Health and Medical Education; Mr Bagher Shoolaieh, CBI Official, National CBI Office, Ministry of Health and Medical Education; Mrs Zahra Salimi, National CBI Office, Ministry of Health and Medical Education; Dr Nazar Elfaki, former Short Term Professional for CBI, WHO Country Office, Islamic Republic of Iran; Ms Sirous Shadrokh, Technical Officer, Health and Sustainable Development Unit, WHO Country Office, Islamic Republic of Iran.

\section{References}

1. Constitution of the World Health Organization. Geneva, World Health Organization, 1946.

2. Sheikh MR. Basic development needs approach in the Eastern Mediterranean Region: from theory to practice. Eastern Mediterranean Health Journal, 2000, 6(4):766-774.

3. Motivalian A. Proposal for evaluation of CBI. Tehran, Islamic Republic of Iran Country Office, 2005.

4. Sheikh MR, Afzal MM. Concepts and methods of communitybased initiatives. Cairo, World Health Organization Regional Office for the Eastern Mediterranean, 2003 (WHO-EM/ $\mathrm{CBI} / 016 / \mathrm{E} / \mathrm{G}$ ).

5. Training manual for community base initiatives. Apractical tool for trainers and trainees. Community based initiatives series 1. Cairo, World Health Organization Regional Office for the Eastern Mediterranean, 2006.

6. Sheikh MR, Afzal MM. CBI training manual for midlevel managers. Module 2: health, health for all and primary health care. Cairo, World Health Organization Regional Office for the Eastern Mediterranean, 2003.

7. Evaluation of the basic development needs programme in the Republic of Yemen. Cairo, World Health Organization Regional Office for the Eastern Mediterranean, 2005 (WHO-EM/ $\mathrm{CBI} / 048 / \mathrm{E})$.
8. Sheikh MR, Afzal MM. Community-based initiatives. Cairo, World Health Organization Regional Office for the Eastern Mediterranean, 2003 (WHO-EM/CBI/017/E/G).

9. CBI success stories. Islamic Republic of Iran. WHO Country Office in Islamic Republic of Iran [website] (http://www.emro. who.int/iran/Media/PDF/CBI_SuccessStories_Iran.pdf, accessed 24 August 2010).

10. Country profile: Islamic Republic of Iran. WHO Country Office in Islamic Republic of Iran [website] (http://www.emro.who. int/iran/countryprofile.htm, accessed 24 August 2010).

11. Putnam R. Making democracy work: civic traditions in modern Italy. Princeton, New Jersey, Princeton University Press, 1993.

12. Sheikh MR, Afzal MM. Guidelines and tools for management of basic development needs. Tool 10: Programme evaluation. Cairo, World Health Organization Regional Office for the Eastern Mediterranean, 2002.

13. Grootaert C, Chase R, van Bastelaer T. The social capital assessment tool (SOCAT). Washington, DC, World Bank, 2002.

14. Joint Committee on Standards for Educational Evaluation. Program evaluation standards. Thousand Oaks, California, Sage Publications, 1994.

15. Validation of the evaluation of community based initiatives in Islamic Republic of Iran. Tehran, World Health Organization Country Office in Islamic Republic of Iran, 2006. 